\title{
Shooting Drills with Target Changes to Improve the Accuracy of Penalty Kick in Soccer
}

\author{
Arif Hidayat \\ Sport Education \\ Universitas Bina Darma Palembang \\ Sumatra Selatan, Indonesia \\ arif.hidayat@binadarma.ac.id
}

\begin{abstract}
The objective of this research was to determine the effect of the drill method on penalty kick accuracy in the students of Prabumulih State High School. A quasi-experimental research design was used to obtain data. A non-probability sampling method was used to select 20 participants for this study. The instrument used was the test and measurement of penalty kick accuracy. The hypothesis was tested using the two-paired t-test. The results showed that drills with target changes had a significant effect on the accuracy of penalty kicks $(1.298>0.688)$, with a percentage increase of $21.5 \%$.
\end{abstract}

Keywords—accuracy, shooting, soccer, changeable target

\section{INTRODUCTION}

Exercise is a structured and rhythmic gesture scenario with a bandage of rules that aim to create a healthy, physical, and mental state of mind. There are various forms of exercise activities in every sport. If viewed from the benefits of sports, every one of these activities should be integrated into the educational curriculum for students.

The physical education curriculum has introduced students participation in several sports, in order to help them develop affective, psychomotor and cognitive intelligence. One of the sports that was introduced is football. Football is categorized as a great ball game (like basketball and volleyball).

It comprises a series of activities with game and fitness values, as well as attitude learning towards the growth of learners. Students must be introduced to a variety of techniques required to play good football. These include passing, shooting, heading, and penalty kick. Various techniques have different levels of difficulty, depending on the need of students. For instance, a player may not be able to control the ball during a penalty kick due to the mental pressure encountered on the field.

Alhadi stated that "...football is played by 2 teams who defend and try to break the opponent's goal ". Sutrisno [7] argued that "...football is a game that is played between players with the aim of scoring goals in the opponents' net" [1]. Football consists of 2 opposing teams, each team consists of 11 players. The duration of the game is an hour and thirty minutes (the duration of each half of the game is forty-five minutes).

According to Luxbacher, it is important to master the basic techniques of playing football. These include dribbling, passing, shooting, heading, stopping the ball (trapping), and throw-in [3].

Bompa stated that "Training is defined as a systematic process of repetitive, progressive and long duration exercises with the ultimate goal of improving athletic performance" [2]. An exercise is defined as a repetitive, progressive and systematic process that helps to improve physical appearance.

The practice of a penalty kick involves kicking the ball from the penalty spot with multiple targets. Goal posts are divided into seven target areas. Participants were required to perform seven kicks in seven different directions, with the freedom to direct the ball to the target area, provided that the direction of the target was changed.

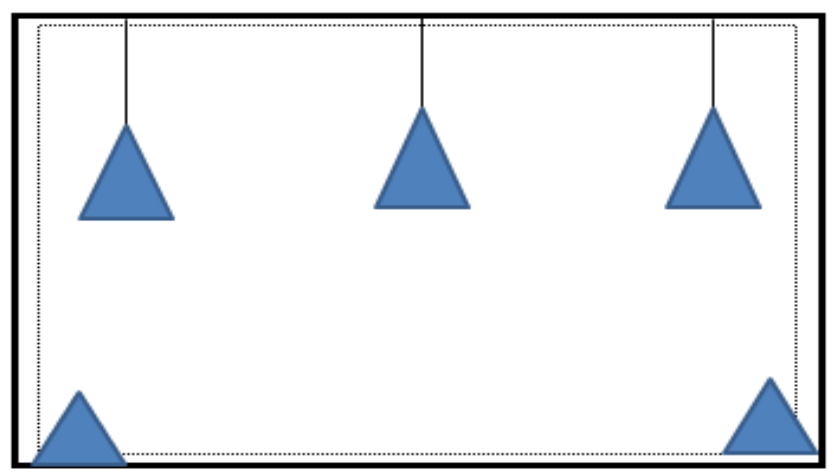

Fig. 1. Goal Change Objectives Source: Researcher (2017)

\section{RESEARCH METHODOLOGY}

\section{A. Types Of Research}

A quantitative research method was used to obtain data. The data was then analyzed using statistical calculations.

\section{B. Design Research}

A Quasi-Experimental design was chosen, due to the difficulty associated with the selection of control groups and the control of different variables. Furthermore, a pretestposttest design was also used in this study. 


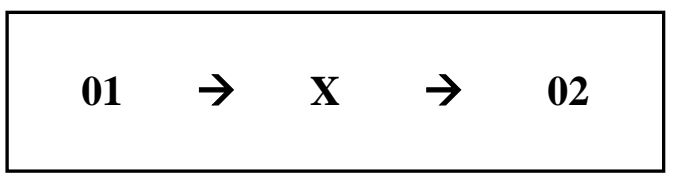

Fig. 2. Research design

Source: Sugiyono, (2015:42)

\section{Sampling Technique}

Sample selection was done using a non-probability sampling method. According to Sugiyono [6], sampling is a technique used in the determination of saturated samples when all the members of a population are the study sample. The participants of this study comprised of 20 students who participate in soccer sports.

TABLE I. SAMPLE RESEARCH

\begin{tabular}{|c|c|c|}
\hline NO & Gender & Amount \\
\hline 1 & Male & 20 \\
\hline
\end{tabular}

(Source: SMA Number 3 Prabumulih Year 2017)

D. Data Collection Technique

The method of data collection includes tests and measurements.

\section{D.1. Research Instrument}

The research instrument used include the test and measurement of the accuracy of penalty kicks.

\begin{tabular}{|c|c|c|}
\hline 5 & 3 & 5 \\
\hline 4 & 1 & 4 \\
\hline 5 & 2 & 5 \\
\hline
\end{tabular}

Fig. 3. Target Accuracy of Penalty Kicks Source: Nurhasan (2001: 129)

Further details about the assessment criteria are shown in Table 2.

TABLE II. ASSESSMENT CRITERIA

\begin{tabular}{|c|c|c|}
\hline No & Interval & Criteria \\
\hline 1 & $<5$ & Low \\
\hline 2 & $6-10$ & Medium \\
\hline 3 & $11-15$ & Good \\
\hline 4 & $>16$ & Excelent \\
\hline
\end{tabular}

Source: Nurhasan (2001: 130)

\section{E. Data Analysis Techniques}

SPSS was used to statistically analyze the data obtained in this study. The steps involved in the performance of data analysis techniques include the following:

E.1. Data Normality Test
Normality test data was calculated by using the Kolmogorov Smirnov Normality Test.

\section{E.2. Homogeneity Test}

The homogeneous distribution of the data was determined using the Levene Statistics Homogeneity Test.

\section{E.3. Test of Hypothesis}

The t-test was used to analyze the normal and homogeneous data at a significance level of 5\%. The degree of freedom was calculated using the formula $=\left(n_{1}+n_{2}-2\right)$.

\section{RESULTS AND DISCUSSION}

\section{A. Description Of The Research}

The results obtained after a pretest and posttest include the following:

\section{A.1. Pretest Data Result}

The ability to kick the football was measured. The result is shown in Figure 4. Pretest result of the students is presented in the form of a bar chart as follows:

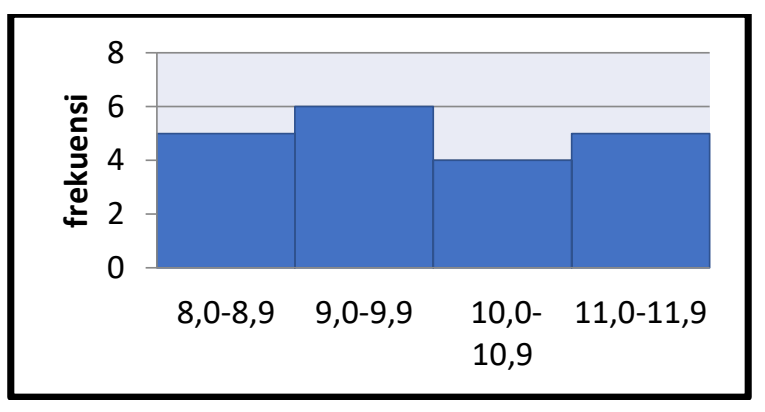

Fig. 4. Pretest result

Figure 4 shows that the pretest results had the highest score of 11 , least score of 8 , an average value of 9.45 and a standard deviation of 1.09. After 6 weeks, the posttest was done to determine the shooting ability kickoff participants.

\section{A.2. Posttest Data Result}

Figure 5 shows the result of the posttest score of students.

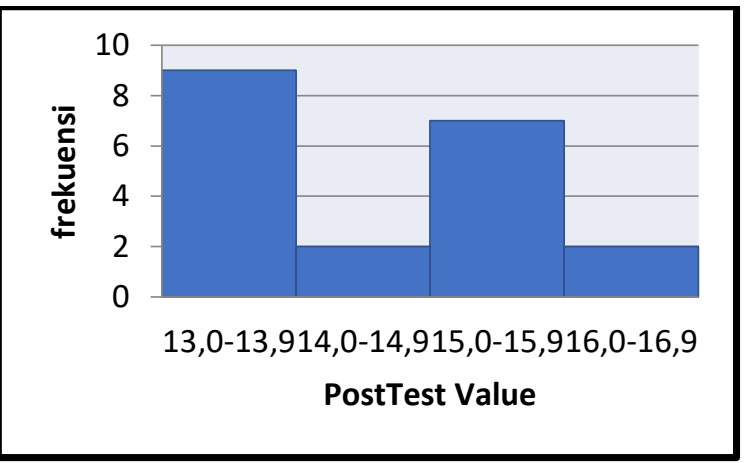

Fig. 5. Post-test result 
The posttest group had the highest score of 16, least score of 13 , an average grade of 14.1 and a standard deviation of 1.28 .

\section{B. Improved Pretest and Posttest Results}

TABLE III. Pre-Test And Post-Test Results Of Penalty SHOOT

\begin{tabular}{|c|c|c|c|}
\hline Group & Pre-test & Pre-test & Improvement \\
\hline Goal Exercise Change & 9.45 & 14.1 & 4.3 \\
\hline
\end{tabular}

Source: Research Documentation

Table 3 shows that there was an average increase of 4.3 or $21.5 \%$ in the target group

\section{Normality Test}

Normality test was carried out before the commencement of data analysis. The result is shown in Table 4.

TABLE IV. ONE-SAMPLE KOLMOGOROV-SMIRNOV TEST

\begin{tabular}{|c|c|c|}
\hline & & $\begin{array}{c}\text { Unstandardized } \\
\text { Residual }\end{array}$ \\
\hline \multicolumn{2}{|l|}{$\mathrm{N}$} & 20 \\
\hline \multirow{2}{*}{$\begin{array}{l}\text { Normal } \\
\text { Parametersa,b }\end{array}$} & Mean & .0000000 \\
\hline & Std. Deviation & 1.08357637 \\
\hline \multirow{3}{*}{$\begin{array}{l}\text { Most Extreme } \\
\text { Differences }\end{array}$} & Absolute & .204 \\
\hline & Positive & .204 \\
\hline & Negative & -.135 \\
\hline \multicolumn{2}{|l|}{ Test Statistic } & .204 \\
\hline \multicolumn{2}{|c|}{ Asymp. Sig. (2-tailed) } & $.280 \mathrm{c}$ \\
\hline \multicolumn{3}{|c|}{$\begin{array}{l}\text { a. Test distribution is Normal. } \\
\text { b. Calculated from data. } \\
\text { c. Lilliefors Significance Correction. }\end{array}$} \\
\hline
\end{tabular}

The Kolmogorov Smirnov value was greater than the level of significance $(0.280>0.05)$. Thus, it can be concluded that the distribution of data is normal.

\section{Homogeneous Data Test}

Homogeneous data tests were carried out to determine the similarity between the variants that make up the sample.

TABLE V. TEST FOR THE HOMOGENEITY OF VARIANCES (PRETESTPOSTTEST)

\begin{tabular}{|c|c|c|c|}
\hline Levene Statistic & $\mathbf{d f}_{\mathbf{1}}$ & $\mathbf{d f}_{\mathbf{2}}$ & Sig. \\
\hline .010 & 1 & 38 & .921 \\
\hline
\end{tabular}

Based on the results of the homogeneity test $(0.921>0.05)$, it can be concluded that the pretest and posttest values for the data distribution were homogeneous.

\section{E. Hypothesis Test}

The hypothesis was tested using the Independent t-test.

TABLE VI. INDEPENDENT SAMPLES TEST

\begin{tabular}{|c|c|c|c|c|c|c|}
\hline & \multicolumn{2}{|c|}{$\begin{array}{c}\text { Levene's Test for } \\
\text { Equality of Variances }\end{array}$} & \multicolumn{3}{|c|}{$\begin{array}{c}\text { t-test for Equality of } \\
\text { Means }\end{array}$} \\
\hline & & $\mathrm{F}$ & Sig. & $\mathrm{t}$ & $\mathrm{f}^{\mathrm{d}}$ & $\begin{array}{l}\text { S } \\
\text { ig. }(2- \\
\text { tailed) }\end{array}$ \\
\hline \multirow{2}{*}{$\begin{array}{l}\text { Pr } \\
\text { ete } \\
\text { st- } \\
\text { Pos } \\
\text { ttes } \\
\text { t }\end{array}$} & $\begin{array}{c}\text { Equal } \\
\text { variances } \\
\text { assumed } \\
\end{array}$ & 010 & ,921 & 1.298 & 38 & .000 \\
\hline & $\begin{array}{c}\text { Equal } \\
\text { variances not } \\
\text { assumed }\end{array}$ & & & 1.298 & 37.979 & .000 \\
\hline
\end{tabular}

Based on the result of the independent t-test $(0.000<0.05)$, it can be concluded that there was a significant difference between the Pretest and Posttest data.

\section{F. Discussion}

The findings generated in this study showed that there was a significant difference in the accuracy of penalty kicks, during drills with target changes. Based on the result of the hypothesis test, it can be concluded that kicking the ball towards different targets improved the accuracy of students' penalty kicks.

Penalty kicks require a high degree of accuracy. The students' level of accuracy can be improved using different forms of exercise. Players can be trained by using fluctuating goals. The main objective of training is to develop the ability to score goals.

\section{CONCLUSION}

Based on the results of this study, the following conclusions were made:

a. There was an increase in the accuracy of penalty kicks (from pretest to posttest) by 4.3 or $21.5 \%$.

b. Based on the t-test results, the hypothesis developed in this study was accepted (1.298> 0.688). Thus, it can be inferred that kicking the ball towards different targets improved the accuracy of student's penalty kicks.

\section{REFERENCES}

[1] Alhadi, Hubungan Koordinasi Mata-Kaki Dengan Hasil Tendangan Penalti, Jakarta: Universitas Negeri Jakarta, 2001.

[2] T. O. Bompa, "Streng n Conditioning", Oxford, 1994.

[3] Luxbacher, Sepak Bola, Bandung: Alfabeta, 2004.

[4] D. Mielke, Latihan Sepak Bola, Bandung: Alfabeta. 2007.

[5] Nurhasan, Tes dan Pengukuran Olahraga, Universitas Terbuka. 2001.

[6] Sugiyono, Metodologi Penelitian, Bandung: Alfabeta, 2008.

[7] Sutrisno, Pendidikan Jasmani, Olahraga dan Kesehatan, Jakarta: Ganesha 2013. 